\title{
Competitive interaction between commom black bean cultivars and Euphorbia heterophylla
}

\author{
Leandro Galon ${ }^{2}$, César Tiago Forte ${ }^{3}$, \\ Francisco Wilson Reichert Júnior ${ }^{4}$, Ricardo Trevisol ${ }^{2}$, Gismael Francisco Perin ${ }^{2}$
}

\begin{abstract}
Weeds can interfere in the growth and development of bean plants if not properly managed, especially the wild poinsettia (Euphorbia heterophylla L.). This study aimed to evaluate the competitive ability of black bean cultivars coexisting with wild poinsettia. The experiment was conducted in a greenhouse, in a completely randomized design, with four replications. Each treatment consisted of one bean plant of the BRS Campeiro, IPR Uirapuru or SCS Predileto cultivars, living with $0,1,2,3,4$ or 5 wild poinsettia plants, corresponding to populations of 0 plants $\mathrm{m}^{-2}, 22$ plants $\mathrm{m}^{-2}, 44$ plants $\mathrm{m}^{-2}$, 66 plants $\mathrm{m}^{-2}, 88$ plants $\mathrm{m}^{-2}$ and 110 plants $\mathrm{m}^{-2}$. Bean and wild poinsettia plants were assessed for stem diameter, leaf area, chlorophyll content, plant height and shoot dry mass. The bean cultivars behaved differently when cultivated with distinct wild poinsettia populations. The SCS Predileto cultivar showed a higher competitive ability against the wild poinsettia than the BRS Campeiro and IPR Uirapuru, what can be verified by the reduction of leaf area and dry mass of the weed. On average, at a density of 110 plants $\mathrm{m}^{-2}$, the wild poinsettia reduces in approximately $32 \%$ the leaf area and $50 \%$ the dry mass of the bean plants.
\end{abstract}

KEYWORDS: Phaseolus vulgaris L.; wild poinsettia; weeds.

\section{INTRODUCTION}

The yield of the black bean crop in Brazil, during the 2016/2017 growing season, was 3.4 million tons, with a mean value of $1,069 \mathrm{~kg} \mathrm{ha}^{-1}$ (Conab 2018). Despite the tradition and importance of the black bean cultivation, this yield is far below those obtained in experimental fields or fields in which advanced technologies are employed.

\section{RESUMO}

Interação competitiva entre cultivares de feijão preto comum e Euphorbia heterophylla

As plantas daninhas podem interferir no crescimento e desenvolvimento do feijoeiro, quando não manejadas de forma correta, com destaque para o leiteiro (Euphorbia heterophylla L.). Objetivou-se avaliar a habilidade competitiva de cultivares de feijão preto em convivência com leiteiro. $\mathrm{O}$ experimento foi conduzido em casa-de-vegetação, em delineamento inteiramente casualizado, com quatro repetições. Cada tratamento consistiu de uma planta de feijão das cultivares BRS Campeiro, IPR Uirapuru ou SCS Predileto, convivendo com $0,1,2,3,4$ ou 5 plantas de leiteiro, correspondendo a populações de 0 plantas $\mathrm{m}^{-2}, 22$ plantas $\mathrm{m}^{-2}, 44$ plantas $\mathrm{m}^{-2}$, 66 plantas $\mathrm{m}^{-2}, 88$ plantas $\mathrm{m}^{-2}$ e 110 plantas $\mathrm{m}^{-2}$. Avaliaram-se o diâmetro de caule, área foliar, teor de clorofila, altura de planta e massa seca da parte aérea, nas plantas de feijão e leiteiro. As cultivares de feijão apresentaram comportamento diferenciado ao conviverem com populações distintas de leiteiro. A cultivar SCS Predileto apresentou maior habilidade competitiva ao leiteiro, em relação à BRS Campeiro e IPR Uirapuru, o que pode ser verificado pela redução na área foliar e massa seca da planta daninha. Em média, em uma densidade de 110 plantas $\mathrm{m}^{-2}$, o leiteiro reduz, aproximadamente, em $32 \%$ a área foliar e em $50 \%$ a massa seca do feijoeiro.

PALAVRAS-CHAVE: Phaseolus vulgaris L.; leiteiro; planta daninha.

Among the reasons for the low yield of beans in Brazilian crops, the inefficient weed control stands out (Teixeira et al. 2009, Barroso et al. 2010). The negative effects of weed interference on beans are manifested in the quantity and quality of grains produced, due to the competition for resources in the environment (Carvalho et al. 2010, Machado et al. 2015).

Wild poinsettia (Euphorbia heterophylla L.) is one of the main weeds growing among crops,

1. Manuscript received in Feb./2018 and accepted for publication in Jul./2018 (http://dx.doi.org/10.1590/1983-40632018v4851669).

2. Universidade Federal da Fronteira Sul, Erechim, RS, Brasil.E-mail/ORCID: leandro.galone@gmail.com/ 0000-0002-1819-462X, gismaelperin@gmail.com/0000-0002-9036-0426, trevisolricardo@gmail.com/0000-0002-3688-8780.

3. Universidade Federal de Santa Maria, Departamento de Fitotecnia, Santa Maria, RS, Brasil.

E-mail/ORCID: cesartiagoforte@hoitmail.com/0000-0001-7211-3096.

4. Universidade Federal de Santa Catarina, Departamento de Recursos Genéticos Vegetais, Florianópolis, SC, Brasil. E-mail/ORCID: chicowrj@gmail.com/0000-0002-4501-898X. 
including beans, and is noted for its wide occurrence in cultivated areas, high competitive ability, high seed production (Kissmann \& Groth 1999) and difficulty of control, when using herbicides (Vargas et al. 2013).

Knowledge on the competitive ability of bean cultivars, with respect to weeds, is a valuable tool for the development of management strategies. Several studies have reported a variation in this ability of cultivars in the presence of weeds, probably due to the particular morphological and physiological characteristics of each crop (Vidal et al. 2010, Kalsing \& Vidal 2013, Agostinetto et al. 2013, Parreira et al. 2014). The competitive capacity of weeds also differs according to the species involved in the community. When using herbicides for management, protoporphyrinogen oxidase inhibitors and aceto lactate synthase must be applied carefully, because wild poinsettia has multiple resistance to their mechanisms of action (Trezzi et al. 2006).

According to Cury et al. (2011), Brachiaria plantaginea and Amaranthus spinosus plants showed a competitive ability higher than Euphorbia heterophylla. However, weeds often take a competitive advantage over crops grown under similar conditions (Galon \& Agostinetto 2009, Agostinetto et al. 2013), and feature a differentiation according to the species, crop, cultivars and populations involved in the competition.

Studies assessing the competitive ability of crops are indispensable, because they combine a more efficient management practice with less environmental impact and lower production cost, and still contribute to prevent the emergence of weeds resistant to herbicides or those considered problematic, as is the case of wild poinsettia.

This study aimed to evaluate the competitive ability of black bean cultivars coexisting with the wild poinsettia weed.

\section{MATERIAL AND METHODS}

The experiment was conducted in a greenhouse at the Universidade Federal da Fronteira Sul, in Erechim, Rio Grande do Sul state, Brazil, in 2014. The experimental design was completely randomized, with four replications, testing three black bean cultivars and six plant densities of wild poinsettia. The experimental units consisted of plastic pots with a capacity of $8 \mathrm{dm}(0.24 \mathrm{~m}$ diameter $\mathrm{x} 0.20 \mathrm{~m}$ in height) filled with Rhodic Hapludox (USDA
2014). The soil correction was carried out according to the technical recommendations for bean crops, and also taking into account the following results: $\mathrm{pH}\left(\mathrm{H}_{2} \mathrm{O}\right)=5.1$; organic matter $=3.0 \%$; clay $=>60 \% ; \mathrm{P}=5.2 \mathrm{mg} \mathrm{dm}^{-3} ; \mathrm{K}=118 \mathrm{mg} \mathrm{dm}^{-3}$; $\mathrm{Ca}^{+2}=5.5 \mathrm{cmol}_{\mathrm{c}} \mathrm{dm}^{-3} ; \mathrm{Mg}^{+2}=3.0 \mathrm{cmol} \mathrm{dm}_{\mathrm{c}}^{-3} ; \mathrm{Al}^{+3}=$ $0.3 \mathrm{cmol}_{\mathrm{c}} \mathrm{dm}^{-3} ; \mathrm{c}+\mathrm{H}+\mathrm{Al}=7.7 \mathrm{cmol}_{\mathrm{c}} \mathrm{dm}^{-3} ;$ and $\mathrm{CEC}=$ $16.6 \mathrm{cmol}_{\mathrm{c}} \mathrm{dm}^{-3}$.

The treatments consisted of one black bean plant of the BRS Campeiro, IPR Uirapuru or SCS Predileto cultivars, in the center of each experimental unit (pot), coexisting with $0,1,2,3,4$ or 5 wild poinsettia plants, corresponding to populations of 0 plants $\mathrm{m}^{-2}, 22$ plants $\mathrm{m}^{-2}, 44$ plants $\mathrm{m}^{-2}$, 66 plants $\mathrm{m}^{-2}, 88$ plants $\mathrm{m}^{-2}$ and 110 plants $\mathrm{m}^{-2}$, respectively (Radosevich et al. 2007). Wild poinsettia population densities were set to cover the probable growing densities that might arise in the fields and to simulate an equally spaced additive series. In the center of the experimental unit, three bean seeds were sown, while, on the outskirts of this unit, 10 seeds of the wild poinsettia biotype were seeded. At 10 days after emergence (DAE), the surplus seedlings were removed, leaving only the specified populations in each treatment.

At 50 DAE, the stem diameter, leaf area, chlorophyll, height and shoot dry mass of the crop plants and weeds were evaluated. The stem diameter was evaluated with a digital caliper, on a millimeter scale, by measuring the plants at the ground level. The leaf area was determined with a portable measuring device (IC-203 Bio Science), by quantifying the leaf area $\left(\mathrm{cm}^{2}\right.$ pot $\left.^{-1}\right)$ of all plants in each treatment. The chlorophyll content was determined by using a portable chlorophyll meter (SPAD 502-Plus) and replication was obtained by averaging 15 observations of the wild poinsettia and bean plants in each experimental unit. The plant height was measured with a ruler, on a millimeter scale, from the ground base to the last leaf/expanded trifoliate. To quantify the shoot dry mass of the species, the plants were sectioned close to the ground, packed in paper bags and subjected to drying in an oven with forced air circulation at $65 \pm 5^{\circ} \mathrm{C}$, until the material reached a constant weight.

The data on the response variables of black bean and wild poinsettia plants were subjected to analysis of variance by the F test. When the treatment effects were significant, further analyses by linear regression for the quantitative factor (wild poinsettia 
plant populations) and by the Tukey test for the qualitative factor (bean cultivars) were performed. All tests were applied at a significance level of $5 \%$.

\section{RESULTS AND DISCUSSION}

Interaction occurred between the tested factors (bean cultivars $\mathrm{x}$ wild poinsettia populations) for all analyzed variables, except for the weed chlorophyll content. The results showed behavioural differences in the response variables depending on the coexistence of bean cultivars with wild poinsettia populations. For the variables leaf area and shoot dry mass of bean and wild poinsettia, a statistical significance $(\mathrm{p}<0.05)$ was verified, when associating the three cultivars with the weed community. However, for the variables bean plant height and wild poinsettia stem diameter, a significant effect was only observed when the SCS Predileto cultivar participated in the association. For the other variables, there were no statistical significant differences in the tested data.

The wild poinsettia leaf area increased linearly as the number of plants competing with all the bean cultivars increased (Figure 1a). The increase in the wild poinsettia plant population (from $22 \mathrm{~m}^{-2}$ to $110 \mathrm{~m}^{-2}$ ) promoted a gain of $7.23,4.86$ and 3.69 times in the weed leaf area, respectively, when in coexistence with the BRS Campeiro, IPR Uirapuru and SCS Predileto cultivars (Figure 1a).

By studying the competitive effect of Jamaican crabgrass with rice and soybean, in a replacement series, Agostinetto et al. (2013) found that the interspecific competition caused more damage to the weed, and, as the proportion of weeds increased, the averages for leaf area and shoot dry mass also increased. In this sense, the cultivars responded differently when in competition with weeds: SCS Predileto showed a greater competitiveness, as, in its presence, reductions in the wild poinsettia leaf growth on the populations of 3, 4 and 5 weeds per pot occurred (Figure 1).

For the other populations and cultivars (BRS Campeiro and IPR Uirapuru) tested, wild poinsettia produced a greater leaf area. It may be noted that, in this situation, an interspecific competition occurred between the beans and the weed, while an intraspecific competition occurred between the wild poinsettia plants, when the species lived together in a community. This corroborates the study of Agostinetto et al. (2013), who evaluated rice and soybean competing with Jamaican crabgrass. Kalsing \& Vidal (2013) also found that bean cultivars competing with alexandergrass behaved differently, and they related this fact to the intrinsic characteristics of the cultivars. Other authors reported differences among bean cultivars in competition with weeds. Barroso et al. (2010) and Parreira et al. (2014) attribute this to characteristics such as growth habit, development cycle and number of branches, which affect the competitive ability of the crop and cause differentiation among the cultivars involved in the competition with weeds.

This fact may be due to the characteristics of the cultivars, which present different development cycles, growth habits and nutritional requirements. Possibly, the high competitive capacity of the SCS Predileto cultivar was associated with its rapid growth
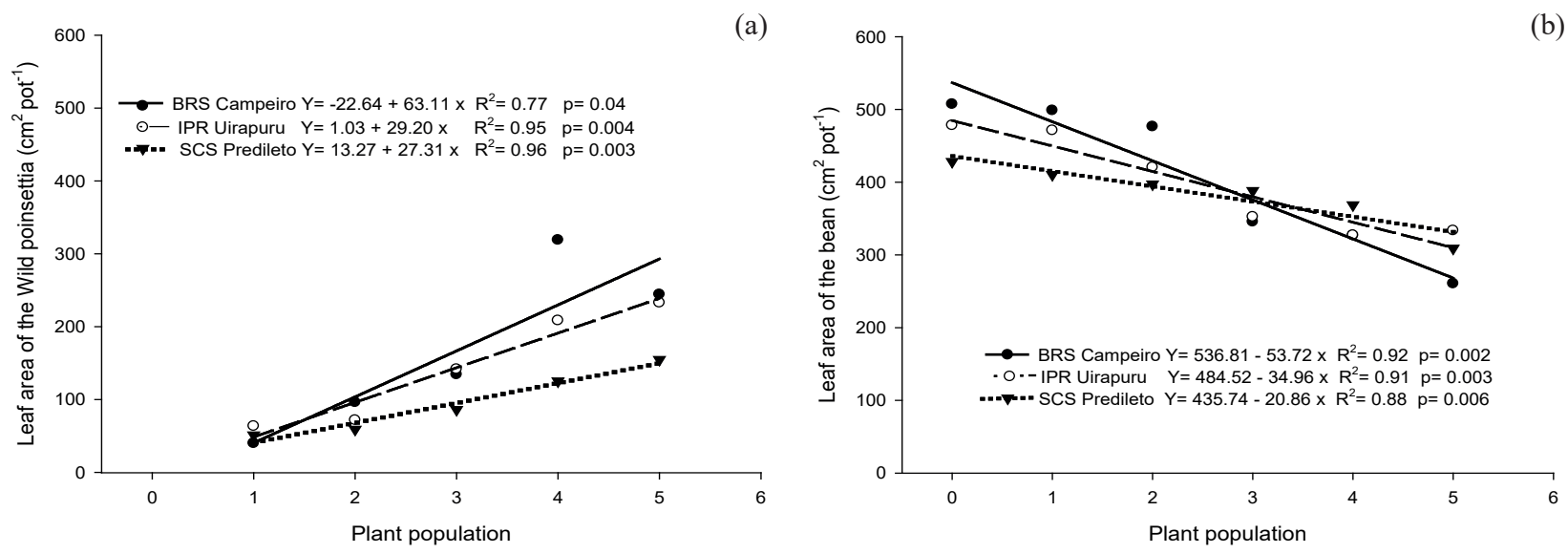

Figure 1. Leaf area $\left(\mathrm{cm}^{2}\right)$ of wild poinsettia (a) and bean (b), due to competition between the black bean cultivars and weed population. 
and shading of the soil, preventing the passage of light and damaging the weed development.

For the leaf area of bean plants, there was less accumulation in all cultivars, when the population of wild poinsettia plants increased. There were reductions of $10.00 \%, 7.21 \%$ and $4.78 \%$, respectively for the BRS Campeiro, IPR Uirapuru and SCS Predileto cultivars, in the presence of only one weed (Figure 1b). The losses, when the absence of wild poinsettia plants was compared to the presence of five plants, were $50.03 \%, 36.08 \%$ and $23.94 \%$, respectively for BRS Campeiro, IPR Uirapuru and SCS Predileto. Carvalho \& Christoffoleti (2008) evaluated the bean competition with different species of Amaranthus spp. and observed that the damage caused by weeds was more closely related to the occurrence of high populations than to the intrinsic competitive ability of the species. Comparing cultivars with each other, in each wild poinsettia population, the results showed, in general, that IPR Uirapuru and SCS Predileto were more competitive, i.e., they had higher leaf areas than the BRS Campeiro cultivar, in the presence of all wild poinsettia populations. Again, there was a differentiation between bean cultivars, when competing with wild poinsettia in this study, what has been explained earlier and also reported by other researchers (Barroso et al. 2010, Vidal et al. 2010, Kalsing \& Vidal 2013, Parreira et al. 2014).

Increasing the wild poinsettia population density resulted in a shoot dry matter accumulation that was higher for weeds and lower for the three cultivars (Figure 2). In the event of one weed per pot infesting the crop, there was a higher dry matter accumulation for both the wild poinsettia and the
SCS Predileto cultivar. However, at the maximum wild poinsettia density ( 5 plants pot $\left.{ }^{-1}\right)$, the values were reversed, since the wild poinsettia had a higher dry matter accumulation in the presence of IPR Uirapuru, intermediate dry matter accumulation in the presence of BRS Campeiro and less production in the presence of SCS Predileto. Regarding the crop shoot dry mass, there was no change, when the weed population increased.

The results showed a gain in dry mass, when the wild poinsettia population increased up to five plants; however, less accumulation occurred in the presence of the SCS Predileto, as it allowed an increase of only $1.88 \mathrm{~g}$ in the dry weight, relatively to the coexistence with one plant. On the other hand, with the other cultivars (BRS Campeiro and IPR Uirapuru), the wild poinsettia dry mass increased by $4.20 \mathrm{~g}$ and $5.92 \mathrm{~g}$, respectively (Figure 2a).

It is noteworthy that the accumulated dry mass of weeds is an important variable, in relation to the degree of interference imposed on the crop (Meschede et al. 2004), because the greater the weed mass, the more competitive the weed, relatively to the crop.

The bean cultivars responded differently, with respect to the dry mass variable, as the weed population increased from one to five plants (Figure 2b). IPR Uirapuru was the cultivar with the lowest accumulation (53.96\%), followed by the SCS Predileto (43.59 \%) and BRS Campeiro (41.62\%). On average, reductions of $0.75 \mathrm{~g}, 0.94 \mathrm{~g}$ and $1.00 \mathrm{~g}$ of dry weight were observed for each additional wild poinsettia plant, respectively in coexistence with the BRS Campeiro, IPR Uirapuru and SCS Predileto.

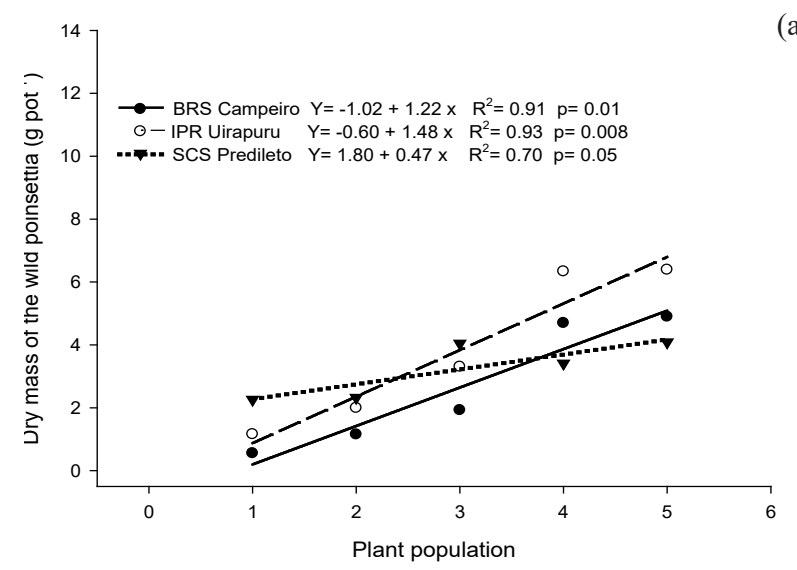

(a)

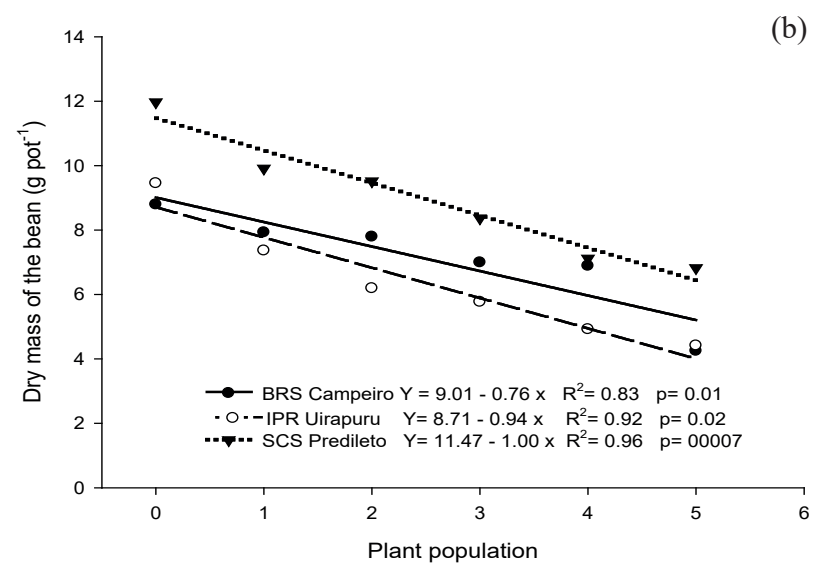

Figure 2. Shoot dry mass ( $\mathrm{g} \mathrm{pot}^{-1}$ ) of wild poinsettia (a) and bean (b), due to the competition of black bean cultivars and weed population. 
A reduced bean dry mass accumulation was also observed by Cury et al. (2011), when beans competed with weeds.

The analysis of the results in Figure 2 showed that, in general, the IPR Uirapuru cultivar allowed, within each wild poinsettia population level, the largest gain in the weeds dry mass, in relation to the other bean cultivars, except for the population of two wild poinsettia plants per pot, where the SCS Predileto cultivar showed less competition than the other cultivars. When the wild poinsettia population increased from four to five plants, BRS Campeiro and SCS Predileto showed the greatest competitive ability against weeds (Figure $2 b$ ). This observation is of particular importance for field situations, because, if the bean crop can live with a greater number of wild poinsettia plants, the use of herbicides to manage this weed can be reduced or even eliminated, resulting in lower production costs and less environmental contamination with herbicides. Silva et al. (2006), studying the competition between bean and Brachiaria brizantha, showed a reduction of approximately $50 \%$ in the accumulation of weed biomass, when compared with the weed monoculture.

The height of wild poinsettia plants was not changed by the coexistence at low population densities with the bean cultivars. However, in larger populations, BRS Campeiro showed an increase in this variable, when in competition with five wild poinsettia plants, differing from the other cultivars. This may be due to the lower competitiveness of the BRS Campeiro, if compared with the other cultivars. It is also hypothesized that the BRS Campeiro shades the wild poinsettia much more than the other cultivars, forcing the weed to seek light, what results in a socalled etiolated plant. This type of plant will invest a large amount of assimilates into growing stems and less into producing biomass, what is reflected on the reduced production of the wild poinsettia dry mass in the presence of the cultivar.

In general, the BRS Campeiro cultivar presented the highest plant height values, when in competition with the highest densities of wild poinsettia. In the absence of wild poinsettia plants, or when bean was cocultured with one weed, there was no differentiation $(\mathrm{p}>0.05)$ among the BRS Campeiro, IPR Uirapuru and SCS Predileto cultivars, in terms of plant height. This shows that, regardless of the cultivar, the coexistence with low wild poinsettia densities will not affect the average crop height. The increasing height of bean plants is probably related to the search for light. According to Braz et al. (2010), the height of soybean plants at harvest is higher when the crop is developed under conditions of coexistence with weeds. Silva et al. (2009) points out that the higher the weed populations in competition with the crop, the higher is the plant height. Contrary to the findings of other researchers, Constantin et al. (2009) reported a negative effect on soybean plant height, when plants were in competition with a higher biomass of weeds.

There was a statistically significant $(\mathrm{p}<0.05)$ decrease in stem diameter with the increasing density of wild poinsettia plants only when the weed competed with the SCS Predileto cultivar: a reduction of $38.1 \%$ from one to five plants of wild poinsettia per pot. The evaluation of the wild poinsettia stem diameter in each population competing with bean plants indicated that a growing density of up to four plants per pot had a negative effect on the weed and, for this condition, the BRS Campeiro cultivar was more competitive than the others. The IPR Uirapuru cultivar caused minor damages to the weed at all the wild poinsettia population densities tested, except for two plants per pot. In the presence of this cultivar, wild poinsettia had the highest stem diameter. At densities greater than four plants per pot, there was no effect of the cultivar on the weed, showing that, at high population densities, the weed has a competitive advantage over the crop.

When the effects of wild poinsettia populations on the stem diamaters of beans were analyzed, there were no significant differences $(p>0.05)$ among the BRS Campeiro, IPR Uirapuru and SCS Predileto cultivars, which presented average stem diameters of $4.70 \mathrm{~mm}, 5.57 \mathrm{~mm}$ and $5.19 \mathrm{~mm}$, respectively.

The chlorophyll contents of both the wild poinsettia plants and bean cultivars showed no relationship to the weed population density for any of the tested cultivars. Average values for chlorophyll of 44.97, 44.37 and 45.83 SPAD were observed for wild poinsettia in the presence of the BRS Campeiro, IPR Uirapuru and SCS Predileto cultivars, respectively, and the cultivars (in the same order) showed chlorophyll index values of 46.56, 38.81 and 41.96 SPAD, in the presence of different wild poinsettia population densities.

There was no significant effect on the chlorophyll content of wild poinsettia within each weed population, in the presence of BRS Campeiro, IPR Uirapuru and SCS Predileto. This leads to the conclusion that, even though there was competition 
between wild poinsettia plants for this variable, the bean cultivars had no effect on the weed. A decrease in the chlorophyll content of the crop, when in competition with weeds, has been observed by other researchers, such as Jakelaitis et al. (2005), who examined this effect on popcorn, and Amaral et al. (2015), who evaluated the influence on chickpea. This does not corroborate the results found in this study for the bean chlorophyll index in the presence of wild poinsettia.

The chlorophyll values measured by SPAD provide the intensity of the green color of leaves and have been used in the quantification of chlorophylls. This quantity may be related to the plant nutritional conditions, especially the nitrogen content. A high value of SPAD indicates a healthy and nutritionally balanced plant. Thus, this effect may be related to the values observed in crops competing for resources from the environment, when in competition with weeds. According to Baker \& Rosenqvist (2004), the decrease in the leaf chlorophyll values is an indication of biotic or abiotic stresses that alter the $\mathrm{CO}_{2}$ absorption capacity, with physiological changes in the photosynthetic activity. Amaral et al. (2015), in a study assessing the competition between chickpea and Amaranthus viridis, Bidens pilosa, Raphanus raphanistrum, Cyperus rotundus, Digitaria nuda and Eleusine indica, indicated changes in the chlorophyll content of the crop. They attributed this to the competition exerted by weeds, especially regarding the availability of nutrients that could have influenced the chlorophyll values, particularly nitrogen. It should be noted that the coexistence between different plants in the same environment causes some stressful relationships, such as competition for resources essential to the plant growth and development (Zimdahl 2004).

Taken together, the results of this study indicate an interference of wild poinsettia on bean cultivars, and the level of competition varies between cultivars and weed population densities in this association. At high population densities, wild poinsettia caused the greatest damage to all evaluated bean cultivars, with reduced values of most the variables.

\section{CONCLUSIONS}

1. There is a competitive interaction between black bean cultivars (BRS Campeiro, IPR Uirapuru and SCS Predileto) and varying populations of
Euphorbia heterophylla (up to 110 plants $\mathrm{m}^{-2}$ of this weed);

2. In general, the SCS Predileto cultivar shows a greater competitive ability against wild poinsettia than BRS Campeiro and IPR Uirapuru, due to the higher reduction in the weed leaf area and shoot dry mass;

3. On average, at a density of 110 plants $\mathrm{m}^{-2}$, the weed reduces in approximately $32 \%$ the leaf area and $50 \%$ the dry mass of the bean plants in the tested cultivars.

\section{REFERENCES}

AGOSTINETTO, D. et al. Habilidade competitiva relativa de milhã em convivência com arroz irrigado e soja. Pesquisa Agropecuária Brasileira, v. 48, n. 10, p. 13151322, 2013.

AMARAL, C. L. et al. Relações de interferência entre plantas daninhas e a cultura do grão-de-bico. Bioscience Journal, v. 31, n. 1, p. 37-46, 2015.

BAKER, N. R.; ROSENQVIST, E. Applications of chlorophyll fluorescence can improve crop production strategies: an examination of future possibilities. Journal of Experimental Botany, v. 55, n. 403, p. 1607-1621, 2004.

BARROSO, A. A. M. et al. Interferência entre espécies de planta daninha e duas cultivares de feijoeiro em duas épocas de semeadura. Bragantia, v. 69, n. 3, p. 609-616, 2010.

BRAZ, G. B. P. et al. Componentes de produção e rendimento de soja em função da época de dessecação e do manejo em pós-emergência. Revista Brasileira de Herbicidas, v. 9, n. 2, p. 63-72, 2010.

CARVALHO, L. B. et al. Interferência de Euphorbia heterophylla no crescimento e acúmulo de macronutrientes da soja. Planta Daninha, v. 28, n. 1, p. 33-39, 2010.

CARVAlHO, S. J. P.; CHRISTOFFOLETI, P. J. Competition of amaranthus species with dry bean plants. Scientia Agricola, v. 65, n. 3, p. 239-245, 2008.

COMPANHIA NACIONAL DE ABASTECIMENTO (Conab). Feijão: Brasil. Série histórica de área, produtividade e produção. 2018. Available at: <http:// www.conab.gov.br/conteudos.php?a $=1252>$. Access on: 25 Feb. 2018.

CONSTANTIN, J. et al. Sistemas de manejo de plantas daninhas no desenvolvimento e na produtividade da soja. Bragantia, v. 68, n. 1, p. 125-135, 2009.

CURY, J. P. et al. Produção e partição de matéria seca de cultivares de feijão em competição com plantas daninhas. Planta Daninha, v. 29, n. 1, p. 149-158, 2011. 
GALON, L.; AGOSTINetTo, D. Comparison of empirical models for predicting yield loss of irrigated rice (Oryza sativa) mixed with Echinochloa spp. Crop Protection, v. 28, n. 10, p. 825-830, 2009.

JAKELAITIS, A. et al. Controle de plantas daninhas na cultura do milho-pipoca com herbicidas aplicados em pósemergência. Planta Daninha, v. 23, n. 3, p. 509-516, 2005.

KALSING, A.; VIDAL, R. A. Nível crítico de dano de papuã em feijão-comum. Planta Daninha, v. 31, n. 4, p. 843-850, 2013.

KISSMANN, K. G.; GROTH, D. Plantas infestantes e nocivas. São Paulo: Basf, 1999.

MACHADO, A. B. et al. Rendimento de grãos de feijão e nível de dano econômico sob dois períodos de competição com Euphorbia heterophylla. Planta Daninha, v. 33, n. 1, p. 41-48, 2015.

MESCHEDE, D. K. et al. Período anterior a interferência de plantas daninhas em soja: estudo de caso com baixo estande e testemunhas duplas. Planta Daninha, v. 22, n. 2, p. 239-246, 2004.

PARREIRA, M. C. et al. Comparação entre métodos para determinar o período anterior à interferência de plantas daninhas em feijoeiros com distintos tipos de hábitos de crescimento. Planta Daninha, v. 32, n. 4, p. 727-738, 2014.

RADOSEVICH, S. R. et al. Ecology of weeds and invasive plants: relationship to agriculture and natural resource management. New Jersey: Wiley-Interscience, 2007.
SILVA, A. C. et al. Consórcio entre feijão e Brachiaria brizantha sob doses reduzidas de graminicida. Planta Daninha, v. 24, n. 1, p. 71-76, 2006.

SILVA, A. F. et al. Interferência de plantas daninhas em diferentes densidades no crescimento da soja. Planta Daninha, v. 27, n. 1, p. 75-84, 2009.

TEIXEIRA, I. R. et al. Competição entre feijoeiros e plantas daninhas em função do tipo de crescimento dos cultivares. Planta Daninha, v. 27, n. 2, p. 235-240, 2009.

TREZZI, M. M. et al. Bioensaios para identificação de biótipos de Euphorbia heterophylla com resistência múltipla a inibidores da ALS e da PROTOX. Planta Daninha, v. 24, n. 3, p. 563-571, 2006.

UNITED STATES DEPARTMENT OF AGRICULTURE (USDA). Soil Survey Staff. Keys to soil taxonomy. 12. ed. Washington DC: Natural Resources Conservation Service, 2014.

VARGAS, L. et al. Práticas de manejo e a resistência de Euphorbia heterophylla aos inibidores da ALS e tolerância ao glyphosate no Rio Grande do Sul. Planta Daninha, v. 31, n. 2, p. 427-432, 2013.

VIDAL, R. A.; KALSING, A.; GHEREKHLOO, J. Interferência e nível de dano econômico de Brachiaria plantaginea e Ipomoea nil na cultura do feijão comum. Ciência Rural, v. 40, n. 8, p. 1675-1681, 2010.

ZIMDAHL, R. L. Weed-crop competition: a review. 2. ed. Chicago: Blackwell Publishing, 2004. 